\title{
Development of a Dispersive Liquid-Liquid Microextraction Followed by LC-MS/MS for Determination of Benzotriazoles in Environmental Waters
}

\author{
Ida Kraševec ${ }^{\star}$ and Helena Prosen \\ Faculty of Chemistry and Chemical Technology, University of Ljubljana, Večna pot 113, Ljubljana, Slovenia \\ ${ }^{*}$ Corresponding author: E-mail: ida.krasevec@fkkt.uni-lj.si
}

Received: $12-18-2018$

\begin{abstract}
Emerging environmental pollutants are becoming a global concern, since the acceptable concentrations are currently not set by legislation in $\mathrm{EU}$ or elsewhere. Benzotriazoles are an important group of emerging pollutants found in low $\mu \mathrm{g} / \mathrm{L}$ concentrations, entering the environment through wastewater treatment facilities due to their insufficient removal, and through industrial and other use. Two new dispersive liquid-liquid microextraction (DLLME) methods were developed for the extraction of hydrophilic and hydrophobic benzotriazoles from environmental waters. Liquid chromatographic method coupled to tandem mass spectrometric detection (LC-MS/MS) was developed and validated for surface water. Validation parameters were satisfactory and the overall DLLME-LC-MS/MS method was found to be applicable to analysis of the chosen analytes in environmental waters. It was used to determine benzotriazoles in surface water and wastewater from a municipal wastewater treatment plant. In surface waters, concentration was below the limit of detection, while concentrations determined in wastewater were estimated between 2.7 and $12.0 \mu \mathrm{g} / \mathrm{L}$.
\end{abstract}

Keywords: Benzotriazoles; dispersive liquid-liquid microextraction; liquid chromatography-mass spectrometry; natural water; wastewater

\section{Introduction}

Benzotriazole and its derivatives are heterocyclic compounds used as anti-corrosive agents in industrial fluids, household dishwasher detergents, de-icing liquids, cooling systems, and hydraulic fluids, while less polar derivatives are used as UV stabilizers in plastics and cosmetics. ${ }^{1}$ Their widespread use has led to a ubiquitous presence in the environment: surface fresh and sea water, ${ }^{2-4}$ groundwater and drinking water, ${ }^{5-7}$ river sediments, ${ }^{8}$ soils, ${ }^{9}$ sewage sludge, ${ }^{10}$ indoor dust, ${ }^{11}$ and air. ${ }^{12}$ Their main point of entry to environmental waters is through the wastewater treatment plants (WWTP) effluents where they are insufficiently removed. ${ }^{13-14}$ A survey from European Union in $2013^{15}$ has shown their presence in $97-100 \%$ of effluent wastewaters (90 WWTPs with various sources) with concentrations in low $\mu \mathrm{g} / \mathrm{L}$ range, while concentrations in untreated wastewaters were up to ten times higher. ${ }^{14}$ Nevertheless, no environmental limit concentrations are set for benzotriazoles in EU yet.

Benzotriazoles are classified as emerging pollutants with low acute toxicity, but their chronic effects are less well known: possible endocrine-disrupting activity ${ }^{16}$ toxicity for plants and some aquatic organisms, ${ }^{17}$ and suspected human carcinogenesis. ${ }^{18}$ Measurable concentrations of benzotriazoles have been found in human urine and amniotic fluid. ${ }^{19-21}$

The concentrations of benzotriazoles in environmental matrices are in the $\mathrm{ng} / \mathrm{L}$ to $\mu \mathrm{g} / \mathrm{L}$ range, therefore it is necessary to perform some form of extraction and preconcentration before the analysis. The most frequently used method is solid-phase extraction (SPE). ${ }^{3,6,21-25}$ Stirbar sorptive extraction (SBSE) ${ }^{26}$ and solid-phase microextraction (SPME) ${ }^{21-27}$ have also been applied.

More recently, liquid-phase microextractions were introduced as an alternative to sorbent-based extraction, but with a very low solvent consumption. One of the most popular is dispersive liquid-liquid microextraction (DLLME), which has to date been applied to the extraction of benzotriazoles only in few instances, ${ }^{28-29}$ in both cases with the use of lighter-than-water solvents, which requires the use of special glassware to collect the solvent. Air-assisted liquid-liquid microextraction, a variant of DLLME, with lighter-than-water solvent, has also been developed for benzotriazoles in water samples. ${ }^{30}$ 
Following the extraction, benzotriazoles are usually determined by chromatographic techniques. HPLC coupled to MS or MS/MS detection is the most frequently applied technique, $2,3,7,10,19,22,23,25-27$ with LODs in the range $0.2-200 \mathrm{ng} / \mathrm{L}$ (depending also on the extraction method), occasionally also with UV detection, ${ }^{28,30}$ which is usually leading to higher LODs. GC-MS or GC-MS/MS methods, either with or without derivatization of analytes, are less frequently encountered, ${ }^{6,13,21,25,29}$ their LODs tend to be comparable or a bit higher than with LC-MS/MS.

In the present work, two DLLME methods were developed and optimized for the extraction of six hydrophilic and two hydrophobic benzotriazoles from aqueous samples. The optimization of DLLME for extraction from water samples with heavier-than-water solvents was done stepwise and with a two-level fractional factorial experimental design. The extracts were analysed with LC-MS/ MS. The method for hydrophilic benzotriazoles was evaluated in terms of the analytical parameters and the efficiency to determine analytes in the environmental aqueous samples. The validated method was applied to the determination of selected benzotriazoles in Slovenian environmental waters.

\section{Experimental}

\section{1. Materials}

Solid standards of the analytes in this study (Table 1) were purchased from Sigma-Aldrich, USA (OHBZ, ClBZ, BTZ, TBZMF, and BZPF), from Fluka, Switzerland (4MBZ, $5 \mathrm{MBZ}$, and DMBZ), or from Santa Cruz Biotechnology, USA (BTZ-d4 as internal standard - IS). Ultrapure water (MQ) was prepared by Milli-Q water system (Millipore, USA). HPLC grade solvents acetonitrile (Fisher Chemical, UK), methanol (J. T. Baker, UK), acetone (Honeywell, USA), and isopropanol (Sigma-Aldrich, USA) were used. Other chemicals were of p.a. or higher purity from various producers: formic acid and $\mathrm{CS}_{2}$ from Sigma-Aldrich (USA), 25\% $\mathrm{NH}_{3}$ from Gram-mol (Croatia), $\mathrm{HCl}$, ethanol, and $\mathrm{CCl}_{3}$ from Honeywell (USA), $\mathrm{NaOH}$ and $\mathrm{CCl}_{4}$ from Merck (USA), $\mathrm{NaCl}$ from Scharlau (Spain), chlorobenzene from Fluka (USA), and 1,1,1-trichloroetane from Codex (Italy).

\section{2. DLLME Extraction}

Extensive optimization of DLLME procedure with heavier-than-water solvents was performed, partially with a two-level fractional factorial experimental design and partially stepwise.

The final conditions for DLLME of hydrophilic and hydrophobic benzotriazoles were: $\mathrm{pH}$ of an aqueous sample $(3 \mathrm{~mL})$ in a conical test tube was adjusted to 3.5 with $\mathrm{HCl}$, and solid $\mathrm{NaCl}$ was added up to $8 \% w / v$. A mixture of $80 \mu \mathrm{L} \mathrm{CHCl}_{3}, 20 \mu \mathrm{L} \mathrm{CCl}_{4}$, and $700 \mu \mathrm{L}$ acetonitrile was quickly injected into the sample. After shaking for $5 \mathrm{~s}$, the mixture was centrifuged at $3000 \mathrm{rpm}$ for $5 \mathrm{~min}$. The extract was collected from the bottom of the tube with a syringe and transferred to a vial, dried under nitrogen and re-dissolved in $50 \mu \mathrm{L}$ of MQ:ACN (3:7).

The final conditions for DLLME of hydrophilic benzotriazoles were: $\mathrm{pH}$ of an aqueous sample $(5 \mathrm{~mL})$ in a conical test tube was adjusted to 4.0 with $\mathrm{HCl}$, and solid $\mathrm{NaCl}$ was added up to $10 \% w / v$. A mixture of $160 \mu \mathrm{L}$ $\mathrm{CHCl}_{3}$ and $800 \mu \mathrm{L}$ acetonitrile was quickly injected into the sample. After shaking for $5 \mathrm{~s}$, the mixture was centrifuged at $3000 \mathrm{rpm}$ for $5 \mathrm{~min}$.

Extract was collected from the bottom of the tube with a syringe and transferred to a vial, dried under nitrogen and re-dissolved in $25 \mu \mathrm{L}$ of MQ.

\section{3. HPLC-DAD and LC-MS/MS Analysis}

DLLME conditions were optimized using an HPLCDAD method with the following parameters: an Agilent 1100 Series HPLC-DAD instrument (Agilent, USA) equipped with autosampler was used. LC separation was performed on a Kinetex XB-C18 column (Phenomenex, USA, $150 \times 4.6 \mathrm{~mm}, 5 \mu \mathrm{m}$ ) at room temperature and flow rate of $0.7 \mathrm{~mL} / \mathrm{min}$. The mobile phase was composed of acetonitrile (A) and $0.1 \% \mathrm{HCOOH}$ in MQ (B), with the following gradient profile: $5 \% \mathrm{~A}$, increased to $50 \% \mathrm{~A}$ in 5.0 min, then to $100 \% \mathrm{~A}$ in $9.0 \mathrm{~min}$ and retained at $100 \% \mathrm{~A}$ for $11.0 \mathrm{~min}$. The injection volume was $20 \mu \mathrm{L}$. UV spectra were recorded in 200-400 $\mathrm{nm}$ range, and detection wavelengths for quantification were set at 260,304, and $350 \mathrm{~nm}$.

LC-MS/MS method for hydrophilic benzotriazoles: a PerkinElmer LC system, coupled with TurboSpray ESI ionization and 3200 QTRAP mass analyser (Sciex, USA)

Table 1: Analyte abbreviations, molecular weights, $\log K_{\text {ow }}$ and $\mathrm{p} K_{\mathrm{a}}$.

\begin{tabular}{llccc}
\hline Abbrev. & Name & $\boldsymbol{M}(\mathbf{g} / \mathbf{m o l})$ & $\log K_{\mathbf{o w}}$ & $\mathbf{p K a}$ \\
\hline OHBZ & 4-hydroxy-1H-benzotriazole & 135.12 & 0.80 & 7.25 \\
BTZ & 1H-benzotriazole & 119.12 & 1.44 & 8.38 \\
4MBZ & 4-methyl-1H-benzotriazole & 133.15 & 1.82 & 8.74 \\
5MBZ & 5-methyl-1H-benzotriazole & 133.15 & 1.98 & 8.74 \\
ClBZ & 5-chloro-1H-benzotriazole & 153.57 & 2.13 & 7.46 \\
DMBZ & 5,6-dimethyl -1H-benzotriazole & 147.18 & 2.28 & 8.92 \\
TBZMF & 2-tert-butyl-6-(5-chloro-2H-benzotriazol-2-yl)-4-methylphenol & 315.80 & 6.81 & 9.31 \\
BZPF & 2-(2H-benzotriazol-2-yl)-4,6-di-tert-pentylphenol & 351.49 & 7.87 & 8.85 \\
\hline
\end{tabular}

Kraševec and Prosen: Development of a Dispersive Liquid-Liquid ... 
was used. LC separation was performed on the same column and with same parameters as for HPLC-DAD, except for the mobile phase gradient. which was as follows: $5 \%$ $\mathrm{A}$, increased to $15 \% \mathrm{~A}$ in $0.5 \mathrm{~min}$, then to $35 \% \mathrm{~A}$ in 12.5 $\mathrm{min}$, then to $100 \% \mathrm{~A}$ in next $7 \mathrm{~min}$. The injection volume was $10 \mu \mathrm{L}$.

Ionization was performed with the electrospray in positive mode with the curtain gas pressure at $30 \mathrm{psi}$, ion spray voltage of $4 \mathrm{kV}$, drying gas temperature at $450{ }^{\circ} \mathrm{C}$, sheath gas 1 at $50 \mathrm{psi}$ and sheath gas 2 at $50 \mathrm{psi}$. Nitrogen, supplied by Messer (Germany), was used both as drying and collision cell gas. The mass spectrometer was operated in selected reaction monitoring (SRM) mode; the declustering potential, entrance potential and collision cell exit potential were fixed at $40 \mathrm{~V}, 10 \mathrm{~V}$, and $3 \mathrm{~V}$, respectively. Transition parameters were optimized for each analyte separately by injecting separate solutions directly into the ion source by flow-injection; two fragment ions were monitored for each compound (Table 2). Quantification was performed as analyte/IS signal ratio, using the first transition for each analyte and BTZ-d4 as the IS, while the second transition and the fragment ion ratio were used for identity confirmation. During sample analysis, the calibration standard at $0.1 \mathrm{mg} / \mathrm{L}$ level and a MQ blank were injected every 12 samples to check for drift in response and carryover effect.

\section{4. Samples}

Grab samples of surface water were taken from the Glinščica $\left(46,050972{ }^{\circ} \mathrm{N}, 14,468536^{\circ} \mathrm{E}\right)$, Soča $(46,152460$ $\left.{ }^{\circ} \mathrm{N}, 13,739944^{\circ} \mathrm{E}\right)$, and Idrijca $\left(46,04803^{\circ} \mathrm{N}, 14,02272^{\circ} \mathrm{E}\right)$ rivers (Slovenia) and two groundwater samples were taken at two different drinking water sources (Roje, PIS) of Ljubljana, Slovenia. Samples were stored in the dark at $4{ }^{\circ} \mathrm{C}$. Influent and effluent municipal wastewater samples in the form of $24 \mathrm{~h}$ composite samples were taken at Central wastewater treatment plant in Ljubljana, Slovenia, and stored at $-20^{\circ} \mathrm{C}$. Due to high matrix effect, which was ob- servable with the use of the internal standard, the influent wastewater sample was diluted 5 times before extraction procedure.

\section{Results and Discussion}

\section{1. Optimization of HPLC-DAD and LC-MS/MS Method}

Two different reverse-phase columns were initially tested to separate polar and hydrophobic analytes in the same run: Kinetex XB-C18 column (Phenomenex, USA, $150 \times 4.6 \mathrm{~mm}, 5 \mu \mathrm{m}, 100 \AA$ ) and Gemini C18 column (Phenomenex, USA, $150 \times 4.6 \mathrm{~mm}, 3 \mu \mathrm{m}, 110 \AA$ ). The Kinetex column provided better resolution of the peaks, which was expected since the sorbent is prepared with core-shell technology, and was selected for further use. The optimization of mobile phase gradient was challenging due to very different polarities of the analytes (Table 1). Therefore, the final gradient started at low acetonitrile percentage (5\%), which was then steeply increased to $50 \%$ and then to $100 \%$ to reach the conditions that were favourable for the elution of hydrophobic benzotriazoles (TBZMF, BZPF). Still, the separation of methyl isomers $4 \mathrm{MBZ}$ and $5 \mathrm{MBZ}$ could not be achieved. These conditions were chosen as final since HPLC-DAD was used only for the optimization of DLLME extraction parameters and the later use of LC-MS/MS in SRM mode enabled us to tolerate the less than satisfactory separation. Wavelengths for quantification were set at 260,304 , and $350 \mathrm{~nm}$ due to different UV spectra of analytes. Under these conditions, the calibration curves for the selected benzotriazoles were linear in the $0.5-50.0 \mathrm{mg} / \mathrm{L}$ range with $\mathrm{R}^{2}>0.99$. An interesting finding was that the standard solutions had to be prepared in a mixture with high percentage of organic solvent to achieve repeatable peak areas for hydrophobic analytes (Figure 1), possibly due to their low solubility in water and adsorption to the walls of the glassware. For this reason all

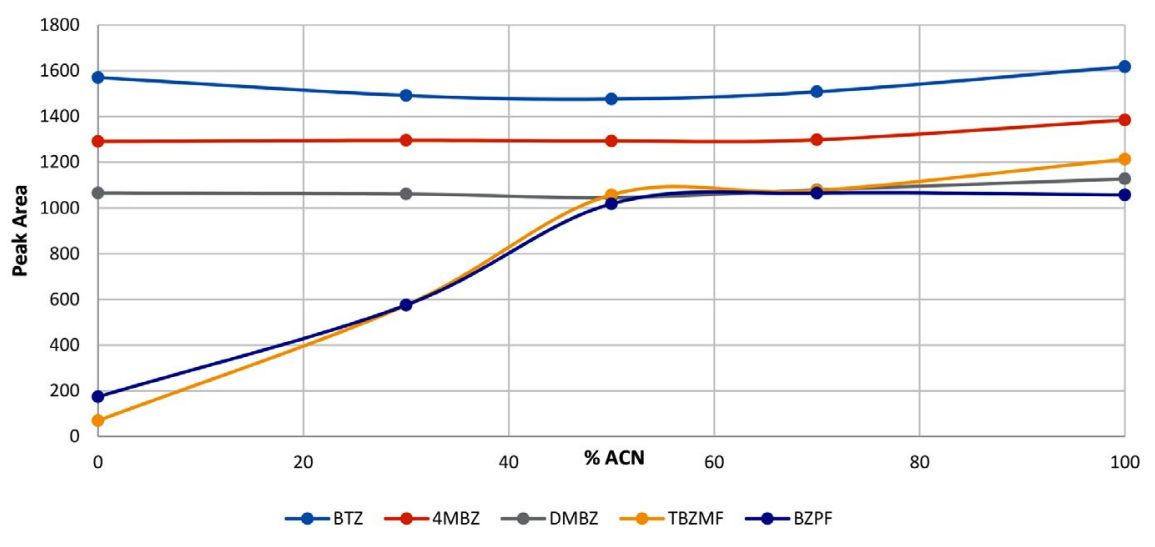

Figure 1: Peak area of different analytes at various compositions of solvent (MQ and acetonitrile) for $50 \mathrm{mg} / \mathrm{L}$ standard solution. 
solutions were prepared in $70 \% \mathrm{ACN}$. A chromatogram of standard solution is given in Supplementary Information SI 1.

Although it would be possible to determine all selected analytes with LC-MS/MS and it was also possible to achieve favourable DLLME extraction conditions for all of them, we decided to omit the two most hydrophobic analytes (TBZMF, BZPF) from further method development since it was highly unlikely that they would be present in aqueous samples due to their hydrophobicity. Therefore, the LC-MS/MS method was optimized only for the hydrophilic benzotriazoles. At this point, a deuterated internal standard (IS; $1 H$-benzotriazole-d4, BTZ-d4) was also introduced. The same chromatographic column was used and the elution gradient started with very low concentration of organic solvent with the slow increase in its percentage ( $35 \% \mathrm{ACN}$ in $12.5 \mathrm{~min}$ ) to achieve the best separation of methyl isomers $4 \mathrm{MBZ}$ and $5 \mathrm{MBZ}$. Even so, their peaks were not baseline separated (see Table 2). A chromatogram of standard solution under final conditions is given in Supplementary Information SI 2.

For MS parameters, electrospray conditions were optimized by flow-injection of analyte solution. Positive ESI ionization was chosen because the signals were of a much higher intensity than with negative ionization, which is in agreement with other published methods. ${ }^{7,22,23}$ The optimized SRM transition conditions are presented in Table 2. The first transition was used for quantification, while the second transition and the fragment ion ratio were used for the identification of analytes.

Table 2: Retention times $\left(t_{\mathrm{R}}\right)$, observed SRM transitions, their collision energies (CE) and fragment ion ratios.

\begin{tabular}{lcccccc}
\hline analyte & $\begin{array}{c}t_{\mathbf{R}} \\
(\mathbf{m i n})\end{array}$ & SRM1 & $\begin{array}{c}\text { CE1 } \\
(\mathbf{V})\end{array}$ & SRM2 & $\begin{array}{c}\text { CE2 } \\
(\mathbf{V})\end{array}$ & $\begin{array}{c}\text { Ion } \\
\text { ratio }\end{array}$ \\
\hline OHBZ & 6.96 & $136>80$ & 29 & $136>90$ & 27 & 9.74 \\
BTZ & 8.63 & $120>65$ & 30 & $120>92$ & 25 & 2.74 \\
$4 \mathrm{MBZ}$ & 11.3 & $134>77$ & 34 & $134>79$ & 25 & 1.46 \\
$5 \mathrm{MBZ}$ & 11.5 & $134>77$ & 34 & $134>79$ & 25 & 1.40 \\
ClBZ & 13.7 & $154>99$ & 32 & $154>73$ & 46 & 2.05 \\
DMBZ & 14.0 & $148>77$ & 37 & $148>91$ & 31 & 1.75 \\
IS & 8.55 & $124>69$ & 33 & $124>96$ & 24 & \\
\hline
\end{tabular}

Instrumental limits of detection (ILOD) and quantification (ILOD) were calculated from calibration curves in standard solutions with added IS, using formulae ILOD = $3.3 \times s(\mathrm{res}) / k$ and ILOD $=10 \times s(\mathrm{res}) / k$, where $s($ res $)$ is the residual sum of squares and $k$ the slope of the calibration curve. ILOD were at 5-30 $\mu \mathrm{g} / \mathrm{L}$, while ILOQ were determined in the range $16-91 \mu \mathrm{g} / \mathrm{L}$. Acceptable linearity of the calibration curve was observed in the range from ILOQ to $10 \mathrm{mg} / \mathrm{L}$.

\section{2. Optimization of DLLME Extraction}

DLLME extraction was studied in MQ water with added analytes at $1 \mathrm{mg} / \mathrm{L}$ level. Two sets of conditions were optimized: for both hydrophilic and hydrophobic benzotriazoles; and for hydrophilic analytes only. The following parameters were changed: choice and volume of extraction solvent; choice and volume of dispersive solvent; volume, $\mathrm{pH}$ and ionic strength of aqueous sample; time and speed of centrifugation. All of the tested extraction solvents were denser than water: dichloromethane, 1,1,1-trichloroethane, $\mathrm{CHCl}_{3}, \mathrm{CS}_{2}, \mathrm{CCl}_{4}$, and chlorobenzene. Solvents with lower density than water (lighter-than-water) can also be applied, ${ }^{28-30}$ but after centrifugation, a thin layer of solvent with extracted compounds is formed on the surface of aqueous phase, which is impossible to collect. For that reason, special glassware with narrow neck should be used to allow for formation of a thicker upper layer of solvent. ${ }^{28-30}$ To avoid the need for special equipment, heavier-than-water solvents were used to form an easy-to-collect drop at the bottom of the vessel after centrifugation. For dispersive solvent, methanol, acetonitrile, acetone, isopropanol, and ethanol were tested. The extract was dried and re-dissolved in MQ or MQ/ACN because of the incompatibility of the chlorinated solvents with the LC column.

Out of all tested extraction solvents, the best recoveries were achieved with $\mathrm{CHCl}_{3}$ for hydrophilic and $\mathrm{CCl}_{4}$ for hydrophobic analytes. A mixture of these solvents was used, the ratios determined in further steps. Acetonitrile proved to be the best dispersive solvent for all analytes.

Optimization of the previously listed parameters was first performed by two-level fractional factorial experimental design, the values of parameters investigated are presented in Table 3.8 different experiments with parameters set at these levels (with 4 repetitions) were performed to estimate the significance of influences of the parameters. For most analytes the only significant parameter seemed to be the $\mathrm{pH}$ value (Figure 2), which could be due to its broad range investigated (4-10). As it is well known that other parameters can also influence the extraction efficiency, we decided to further perform a stepwise optimization.

Table 3: Values of parameters, investigated with fractional factorial design.

\begin{tabular}{lcc}
\hline Parameter & Level - & Level + \\
\hline Sample volume $(\mathrm{mL})$ & 2 & 5 \\
$\mathrm{CHCl}_{3}$ volume $(\mu \mathrm{L})$ & 20 & 100 \\
$\mathrm{CCl}_{4}$ volume $(\mu \mathrm{L})$ & 20 & 100 \\
ACN volume $(\mathrm{mL})$ & 0,3 & 1 \\
Sample pH & 4 & 10 \\
NaCl $(\% w / v)$ & 0 & 10 \\
rpm & 1500 & 3000 \\
\hline
\end{tabular}




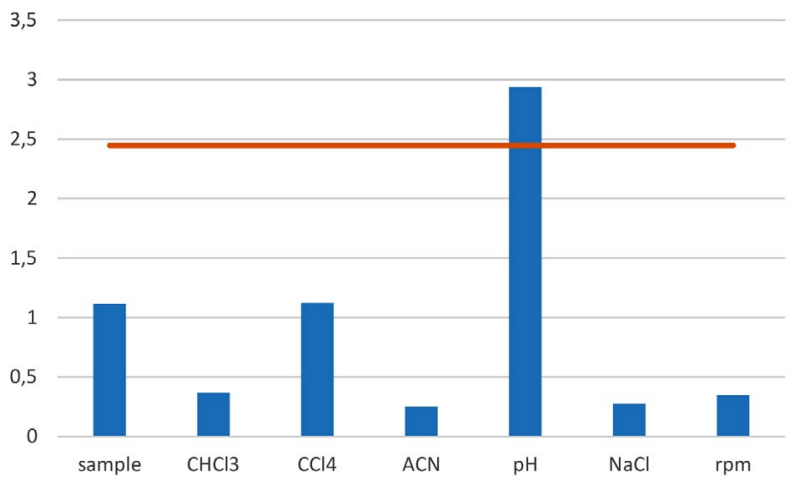

Figure 2: Influence of investigated parameters on $4 \mathrm{MBZ}$ extraction efficiency, the line denotes significant influence.

In the stepwise optimization it turned out, that sample $\mathrm{pH}$ below 6 was necessary for efficient extraction of hydrophilic compounds and that the addition of salt up to $10 \% \mathrm{w} / \mathrm{v}$ improved the extraction for the hydrophilic analytes, while the hydrophobic analytes remained unaffected. Variations in centrifugation speed and time had almost no effect on extraction efficiency, while smaller sample volumes and larger solvent volumes increased the efficiency for all analytes. Due to aiming for higher enrichment factors (not recoveries), the ratio between sample and extract volume was adjusted further, with sample volume set at $3 \mathrm{~mL}$ and final solvent volumes $80 \mu \mathrm{L} \mathrm{CHCl}_{3}$, $20 \mu \mathrm{L} \mathrm{CCl}_{4}$, and $700 \mu \mathrm{L}$ acetonitrile, which resulted in 200-220 $\mu \mathrm{L}$ of extract before drying. With the parameters set as described in Experimental, the enrichment factors ranged between 9.5 and 28.7. Further experimental data on this optimization is given in Supplementary Information (SI3-5).

For hydrophilic analytes, only $\mathrm{CHCl}_{3}$ was used as the extraction solvent, as the addition of $\mathrm{CCl}_{4}$ was unnecessary. The best enrichment factors in general were obtained with the $\mathrm{CHCl}_{3}$ /acetonitrile ratio 1:5 (Figure 3) and the highest available sample volume $(5 \mathrm{~mL})$. Relatively high volumes of solvents contributed to higher enrichment factors due to the additional concentrating step (drying and re-dissolving). Again, the acidic $\mathrm{pH}$ and salt addition in-

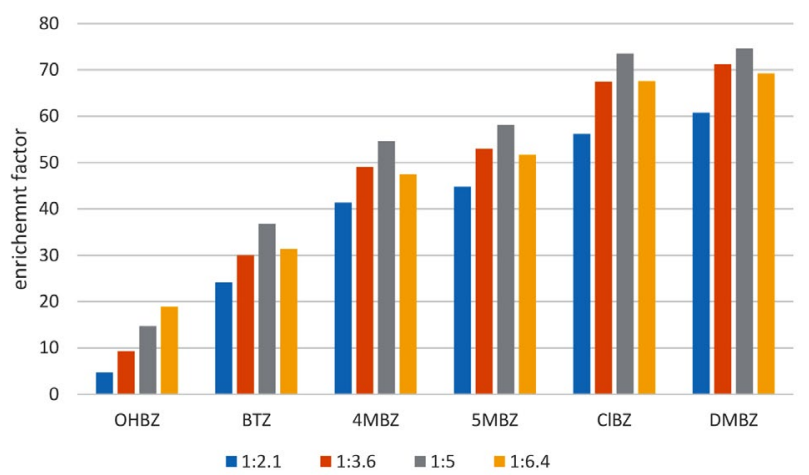

Figure 3: The effect of solvent ratios $\left(\mathrm{CHCl}_{3}: \mathrm{ACN}\right)$ on enrichment factors for hydrophilic analytes. creased the efficiency, while the centrifugation speed and time had negligible effect. While the addition of $15 \% \mathrm{w} / \mathrm{v}$ of $\mathrm{NaCl}$ further increased the efficiency, the density of the sample increased to such amount, that the extract floated to the surface, and the repeatability dropped drastically. With the final parameters, the obtained enrichment factors ranged from 9.5 to 84.7 .

\section{3. Validation of the Method in Environmental Samples}

DLLME method for hydrophilic analytes in surface water in combination with LC-MS/MS analytical method was evaluated for enrichment factor, linearity, repeatability, limit of detection, and limit of quantification, using matrix matched calibration. River water was spiked with analytes in the range $0.01-50 \mu \mathrm{g} / \mathrm{L}$ and $1 \mu \mathrm{g} / \mathrm{L}$ of IS, and then extracted by the optimized DLLME procedure. The repeatability was estimated at two concentration levels $(0.5$ and $10 \mu \mathrm{g} / \mathrm{L})$ in at least 3 replicates, and blank river water extracts were also prepared. All signals were calculated as the ratio of peak areas of analytes and IS. The validation results are shown in Table 4. High linearity was observed from LOQ to $10 \mu \mathrm{g} / \mathrm{L}$ for all analytes $\left(\mathrm{R}^{2} 0.9901-\right.$ 0.9985 , except for OHBZ 0.9827). Moreover, the matrix effect (ME) was estimated by comparing the signal of the blank extract, spiked with the analytes and IS (post-extraction spiking), and the signal of the standard solutions in MQ water at the same theoretical concentration. Negative values of ME indicate ionization suppression in ESI, while positive $\mathrm{ME}$ values indicate ionization enhancement. Interestingly, $\mathrm{ME}$ is in the range $+15 \%$ to $+31 \%$, except for BTZ (-19\%). Matrix effect is commonly explained by the co-elution of compounds from the sample matrix that are still present in the sample extract and compete with analytes during the ESI ionization process. Positive ME values are in fact favourable because lower LODs can be achieved, but nevertheless, matrix-matched calibration should be used for the quantitative determination of analytes in real samples. As seen from Table 4, LODs and LOQs are sufficiently low to cover the expected range of concentrations in wastewater, ${ }^{14,15}$ while using only $5 \mathrm{~mL}$ of sample, which is much lower compared to sample volumes usually required for SPE. ${ }^{3,6,21-25}$ Extraction efficiency, given as enrichment factor (EF), is calculated by comparing concentration in the extract and initial concentration in sample. It is obvious that EFs for the most polar analytes (OHBZ, BTZ) are lower than EFs for the other analytes, which results from their lower solubility in the non-polar extraction solvent. Repeatability is acceptable at higher spiking level, but it is obvious that DLLME is a manual technique requiring a highly skilled operator. On the lower spiking level, the repeatability decreases, even with the use of an internal standard, but this is understandable, since this level is close to or below LOQs. 
Table 4: Method validation parameters in surface water.

\begin{tabular}{lcccccc}
\hline & OHBZ & BTZ & 4MBZ & 5MBZ & ClBZ & DMBZ \\
\hline LOD $(\mu \mathrm{g} / \mathrm{L})$ & 0.07 & 0.14 & 0.75 & 0.19 & 0.06 & 0.04 \\
LOQ $(\boldsymbol{\mu g} / \mathbf{L})$ & 0.23 & 0.47 & 2.51 & 0.62 & 0.19 & 0.14 \\
$\mathbf{\% R S D}$ & 19.4 & 4.4 & 8.8 & 10.7 & 12.1 & 16.2 \\
$(\mathbf{1 0} \boldsymbol{\mu g} / \mathbf{L})$ & & & & & & \\
$\mathbf{\% R S D}$ & 44.0 & 42.4 & 35.2 & 24.4 & 16.8 & 14.3 \\
$(\mathbf{0 . 5} \boldsymbol{\mu g} / \mathbf{L})$ & & & & & & \\
$\mathbf{E F}^{\mathbf{a}}$ & 10 & 34 & 75 & 66 & 81 & 70 \\
\hline
\end{tabular}

${ }^{\mathrm{a}} \mathrm{EF}$ - enrichment factors, determined at spiking concentration $5 \mu \mathrm{g} / \mathrm{L}$

\section{4. Comparison to Other DLLME Methods for Benzotriazoles}

Three other DLLME or similar methods were found in the literature for the determination of polar benzotriazoles. The comparison of methods from the analytical standpoint is presented in Table 5. Pena et al. ${ }^{28}$ used $100 \mu \mathrm{L}$ of the ionic liquid tri-butyl-phosphate as the extraction solvent, but due to the high viscosity of the ionic liquid, the extract had to be diluted 10-times before injection into LC-Flu-UV. In our method, the recoveries are lower, but no ionic liquids are used, so it is not necessary to dilute the extract and further preconcentration is gained with the drying step and the LOQs achieved are quite similar. Casado et al..$^{29}$ used $60 \mu \mathrm{L}$ of toluene as the extraction solvent with $100 \mu \mathrm{L}$ of acetic anhydride added for simultaneous acetylation of the analytes, which were then analysed by GC-MS. With this method, they obtained very low LOQs, but the recoveries are comparable to those obtained with our method, with the exception of the most polar analyte (OHBZ) which was not analysed in their study. Lu et al. ${ }^{30}$ used $80 \mu \mathrm{L}$ of 1-hexanol extraction solvent, which was dispersed with the assistance of air instead of a dispersive solvent. The extracts were analysed by HPLC-UV, which also contributes to the higher LOQs in comparison to our method's.

In general, our method is comparable to those from the literature. For all of these methods, the extracts were lighter-than-water, which demanded either special glassware or a twofold transferring of the extract for exact separation of the phases. In this work, we managed to avoid these disadvantages connected to the use of heavier-thanwater solvents.
In comparison to conventional SPE methods, for which the reported LOQs range from 1 to $100 \mathrm{ng} / \mathrm{L}, 3,6,22,23,25$ the LOQs obtained with all of these DLLME methods are quite higher. This is a direct consequence of lower sample volumes, which reduces the possible preconcentration factors.

\section{5. Determination of Benzotriazoles in Environmental Samples}

The developed and validated method was applied to the determination of analytes in environmental water samples. The quantification was performed with matrix-matched calibration. In groundwater and rivers Glinščica, Idrijca, and Soča, all analytes were below LOD of the method, while BTZ, $4 \mathrm{MBZ}$, and $5 \mathrm{MBZ}$ were found in influent and effluent wastewaters from the Central wastewater treatment plant in Ljubljana. Estimated concentrations in effluent wastewater ranged from 4.8 to 7.3 $\mu \mathrm{g} / \mathrm{L}$. In influent wastewater, the same analytes were present in estimated concentrations 2.7 to $12.0 \mu \mathrm{g} / \mathrm{L}$. Influent water was diluted 1:5 with MQ water before extraction due to enhanced matrix effect compared to surface water. However, for accurate quantification, matrix-matched calibration for wastewater should be applied.

The concentrations for wastewater are in good agreement with those usually determined in European wastewaters. ${ }^{14,15}$ In a recent study on micropollutants in surface and groundwater from the area of Maribor, Slovenia, where SPE extraction was performed (LOQs 3-7 ng/L), two benzotriazoles (2-methyl-2H-benzotriazole, 2,4-dimethyl-2H-benzotriazole) were found in concentrations 1.4 to $273.3 \mathrm{ng} / \mathrm{L}$ in groundwater, and in concentrations 5.8 to $27.9 \mathrm{ng} / \mathrm{L}$ in surface water. ${ }^{31}$ These two compounds were not considered in our method.

\section{Conclusions}

In this study, two DLLME microextraction methods were developed for the determination of either hydrophilic benzotriazoles, or hydrophilic and hydrophobic benzotriazoles together. Especially the hydrophilic benzotriazoles are emerging pollutants present in the aquatic system. Microextraction methods for benzotriazoles are rarely encountered in literature, and to our best knowledge, this is

Table 5: Comparison of analytical performance in pure water with DLLME methods from literature (EF - enrichment factor, RSD - repeatability).

\begin{tabular}{|c|c|c|c|c|c|}
\hline Analytes & EF & $\begin{array}{c}\text { Absolute recovery } \\
(\%)\end{array}$ & $\begin{array}{c}\text { RSD (\%) } \\
\text { (at spiking level) }\end{array}$ & LOQ & Ref. \\
\hline OHBZ, BTZ, 4MBZ, 5MBZ, ClBZ, DMBZ & ND & $67-86$ & $5.0-7.8(18 \mu \mathrm{g} / \mathrm{L})$ & $0.1-7.3 \mu \mathrm{g} / \mathrm{L}$ & 28 \\
\hline BTZ, 4MBZ, 5MBZ, ClBZ, DMBZ & $93-172$ & $24-46$ & $2-8(0.2 \mu \mathrm{g} / \mathrm{L})$ & $7-80 \mathrm{ng} / \mathrm{L}$ & 29 \\
\hline $\mathrm{BTZ}, 5 \mathrm{MBZ}, \mathrm{ClBZ}$ & $43-87$ & ND & $3.0-4.3(50 \mu \mathrm{g} / \mathrm{L})$ & $2.9-4.8 \mu \mathrm{g} / \mathrm{L}$ & 30 \\
\hline OHBZ, BTZ, 4MBZ, 5MBZ, ClBZ, DMBZ & $10-85$ & $5-42$ & $4.7-13(50 \mu \mathrm{g} / \mathrm{L})$ & $0.1-2.5 \mu \mathrm{g} / \mathrm{La}$ & This work \\
\hline
\end{tabular}

ND - no data available; ${ }^{a}$ In surface water 
the first time a DLLME method with denser-than-water extracts for benzotriazoles has been developed. The developed methods use smaller volumes of samples and solvents than classical methods and in this aspect contribute to a more environmentally friendly chemistry. The DLLME method for hydrophilic benzotriazoles was validated in surface water. Matrix effect was compensated for in sample analysis with the usage of matrix matched calibration.

The method was applied for determination of analytes in groundwater, surface water and wastewater samples. However, in wastewater samples the matrix effect was more pronounced than in surface water. Therefore, matrix-matched calibration using wastewater matrix should be applied for accurate quantification. This study was also one of the very few investigating the presence of benzotriazoles in Slovenian water environment. We confirmed their presence in the wastewater at $\mu \mathrm{g} / \mathrm{L}$ levels, comparable to other European samples, but the analytes were $<$ LOD in river and groundwater samples.

Both DLLME methods could also be applied in analysis of solid samples, such as sediments and soil, where more hydrophobic analytes can be expected. In this case, the analytes from solid samples would be first extracted into a liquid phase (with one of conventional methods), and then these extracts would be cleaned and preconcentrated through the use of DLLME.

\section{Acknowledgments}

The authors acknowledge the financial support from the Slovenian Research Agency (research core funding No. P1-0153). I. Kraševec has received the grant from Slovenian Research Agency (MR 38132). We would also like to express our thanks to Primož Auersperger, MSc, and Vlasta Kramarič Zidar at JP Vodovod-Kanalizacija, who supplied us with groundwater and wastewater samples.

\section{References}

1. P. Herrero, F. Borrull, E. Pocurull, R. M. Marcé, Trends Anal. Chem. 2014, 62, 46-55. DOI:10.1016/j.trac.2014.06.017

2. S. Weiss, T. Reemtsma, Anal. Chem. 2005, 77, 7415-7420. DOI:10.1021/ac051203e

3. P. Herrero, F. Borrull, E. Pocurull, R. M. Marcé, J. Chromatogr. A 2013, 1309, 22-32. DOI:10.1016/j.chroma.2013.08.018

4. A. Kiss, E. Fries, Environ. Sci. Pollut. Res. 2009, 16, 702-710. DOI:10.1007/s11356-009-0179-4

5. H. Janna, M. D. Scrimshaw, R. J. Williams, J. Churchley, J. P. Sumpter, Environ. Sci. Technol. 2011, 45, 3858-3864.

DOI:10.1021/es103267g

6. Y.-S. Liu, G.-G. Ying, A. Shareef, R. S. Kookana, J. Chromatogr. A 2011, 1218, 5328-5335.

DOI:10.1016/j.chroma.2011.05.100

7. L. Wang, J. Zhang, H. Sun, Q. Zhou, Q. Environ. Sci. Technol.
2016, 50, 2709-2717. DOI:10.1021/acs.est.5b06093

8. M. G. Cantwell, J. C. Sullivan, D. R. Katz, R. M. Burgess, J. Bradford Hubeny, J. King, Mar. Pollut. Bull. 2015, 101, 208 218. DOI:10.1016/j.marpolbul.2015.10.075

9. A. Speltini, M. Sturini, F. Maraschi, A. Porta, A. Profumo, Talanta 2016, 147, 322-327.

DOI:10.1016/j.talanta.2015.09.074

10. P. Herrero, F. Borrull, R. M. Marcé, E. Pocurull, J. Chromatogr. A 2014, 1355, 53-60. DOI:10.1016/j.chroma.2014.05.086

11. L. Wang, A. G. Asimakopoulos, H. B. Moon, H. Nakata, K. Kannan, Environ. Sci. Technol. 2013, 47, 4752-4759. DOI:10.1021/es305000d

12. J. Xue, Y. Wan, K. Kannan, Toxicol. Environ. Chem. 2017, 99, 402-414. DOI:10.1080/02772248.2016.1196208

13. Y. S. Liu, G. G. Ying, A. Shareef, R. S. Kookana, Environ. Pollut. 2012, 165, 225-232. DOI:10.1016/j.envpol.2011.10.009

14. T. Reemtsma, U. Miehe, U. Duennbier, M. Jekel, Water Res. 2010, 44, 596-604. DOI:10.1016/j.watres.2009.07.016

15. R. Loos, R. Carvalho, D. C. Antonio, S. Cornero, G. Locoro, S. Tavazzi, B. Paracchini, M. Ghiani, T. Lettieri, L. Blaha, Water Res. 2013, 47, 6475-6487. DOI:10.1016/j.watres.2013.08.024

16. C. A. Harris, E. J. Routledge, C. Schaffner, J. V. Brian, W. Giger, J. P. Sumpter, Environ. Toxicol. Chem. 2007, 26, 23672372. DOI:10.1897/06-587R.1

17. A. Seeland, M. Oetken, A. Kiss, E. Fries, J. Oehlmann, Environ. Sci. Pollut. Res. 2012, 19, 1781-1790.

DOI:10.1007/s11356-011-0705-Z

18. Health Council of the Netherlands, 1,2,3-Benzotriazole. Health-based recommended occupational exposure limit. The Hague: Health Council of the Netherlands, publication no. 2000/14OSH-2000.

19. A. G. Asimakopoulos, A. A. Bletsou, Q. Wu, N. S. Thomaidis, K. Kannan, Anal. Chem. 2013, 85, 441-448. DOI:10.1021/ac303266m

20. X. Li, L. Wang, A. G. Asimakopoulos, H. Sun, Z. Zhao, J. Zhang, L. Zhang, Q. Wang, Chemosphere 2018, 199, 524-530. DOI:10.1016/j.chemosphere.2018.02.076

21. A. Naccarato, E. Gionfriddo, G. Sindona, A. Tagarelli, J. Chromatogr. A 2014, 1338, 164-173.

DOI:10.1016/j.chroma.2014.02.089

22. D. Salas, F. Borrull, R. M. Marcé, N. Fontanals, J. Chromatogr. A 2016, 1444, 21-31. DOI:10.1016/j.chroma.2016.03.053

23. J. A. van Leerdam, A. C. Hogenboom, M. M. van der Kooi, P. de Voogt, Int. J. Mass Spectrom. 2009, 282, 99-107. DOI:10.1016/j.ijms.2009.02.018

24. I. Kraševec, H. Prosen, Molecules 2018, 23, 2501-2514. DOI:10.3390/molecules23102501

25. E. Jover, V. Matamoros, J. M. Bayona, J. Chromatogr. A 2009, 1216, 4013-4019. DOI:10.1016/j.chroma.2009.02.052

26. N. Gilart, P. A. G. Cormack, R. M. Marcé, F. Borrull, N. Fontanals, J. Chromatogr. A 2013, 1295, 42-47.

DOI:10.1016/j.chroma.2013.04.067

27. J. Casado, I. Rodríguez, M. Ramil, R. Cela, J. Chromatogr. A 2013, 1299, 40-47. DOI:10.1016/j.chroma.2013.05.061

28. M. T. Pena, X. Vecino-Bello, M. C. Casais, M. C. Mejuto, R. Cela, Anal. Bioanal. Chem. 2012, 402, 1679-1695. 
DOI:10.1007/s00216-011-5598-7

29. J. Casado, R. Nescatelli, I. Rodríguez, M. Ramil, F. Marini, R. Cela, J. Chromatogr. A 2014, 1336, 1-9.

DOI:10.1016/j.chroma.2014.01.068
30. J. Lu, M.-M. Wang, Q. Wang, H.-P. Li, Z.-G. Yang, Chinese J. Anal. Chem. 2018, 46, e1817-e1824.

31. A. Koroša, P. Auersperger, N. Mali, Sci. Total Environ. 2016, 571, 1419-1431. DOI:10.1016/S1872-2040(17)61082-X

\section{Povzetek}

Nova okoljska onesnaževala postajajo svetovni problem, tudi zato, ker EU ali druga zakonodaja ne predpisuje meja njihovih sprejemljivih koncentracij. Benzotriazoli so pomembna skupina novih onesnaževal, ki jih v okolju najdemo v koncentracijskem območju nizkih $\mu \mathrm{g} / \mathrm{L}$, vanj pa vstopajo pretežno skozi čistilne naprave zaradi slabe razgradnje, pa tudi preko industrijske in druge rabe. $\mathrm{V}$ tem delu smo razvili dve novi disperzivni tekočinski mikroekstrakcijski metodi (DLLME) za ekstrakcijo hidrofilnih in hidrofobnih benzotriazolov iz okoljskih voda. Razvili in validirali smo tudi analizno metodo s tekočinsko kromatografijo sklopljeno s tandemsko masno spektrometrijo (LC-MS/MS) za določitve v površinski vodi. Validacijski parametri so bili zadovoljivi in celotna DLLME-LC-MS/MS metoda se je izkazala za primerno za analizo izbranih analitov v okoljskih vodah. $\mathrm{Z}$ njo smo določali benzotriazole v površinskih in odpadnih vodah iz komunalne čistilne naprave. V površinskih vodah so bile koncentracije pod mejo zaznave, koncentracije v odpadnih vodah pa smo ocenili na $2,7-12 \mu \mathrm{g} / \mathrm{L}$. 